\title{
Habitat Preference and Overnight and Seasonal Variation in the Foraging Activity of Lesser Horseshoe Bats
}

\author{
Catherine M. McANEY \& James S. FAIRLEY
}

\begin{abstract}
McAney C.M. \& Fairley J.S., 1988: Habitat preference and overnight and seasonal variation in the foraging activity of lesser horseshoe bats. Acta theriol., 33, 28: 393-402. [With 4 Tables].

The ultrasonic foraging pulses of the lesser horseshoe bat Rhinolophus hipposideros (Bechstein, 1800) were monitored repeatedly at night from May to September for sample periods of $15 \mathrm{~min}$ at a variety of sites in two districts in western Ireland, predominantly of permanent pasture. Pulses were commonest by water and over farmyards, less frequent along trees and hedgerows, and relatively rare over open pasture. Feeding activity decreased overnight, although bats were still active before dawn, and also increased towards the end of the summer. The possible reasons for these spatial and temporal feeding patterns are discussed.
\end{abstract}

[Department of Zoology, University College, Galway, Ireland]

\section{INTRODUCTION}

The lesser horseshoe bat Rhinolophus hipposideros (Bechstein, 1800) is widely distributed in the South-western Palaearctic. Though once common, numbers are now severely reduced over most of its range in Europe (Stebbings \& Griffith, 1986). Although there is a substantial body of knowledge of the behavioural ecology of this species in summer, notably through the studies of Gaisler (1963a, 1963b, 1963c) in Czechoslovakia, almost nothing is known of its foraging activity away from roosts in spatial and temporal terms. This paper forms part of a larger research programme on the species at the western limit of its range, in County Clare $\left(52^{\circ} 34^{\prime}-53^{\circ} 10^{\prime} \mathrm{N} 8^{\circ} 19^{\prime}-9^{\circ} 57^{\prime} \mathrm{W}\right)$ in Ireland. Because of the endangered status of the lesser horseshoe and its high susceptibility to disturbance, all handling was ruled out during the programme, and thus radio or light tagging. In the present study the ultrasonic sound pulses used in foraging were monitored frequently in the field using a bat detector at a variety of sites and times of night from May to September. The data accumulated were tested for possible differences in intensity of foraging over the season, from dusk to dawn and between habitats. 


\section{STUDY AREAS}

Operations were restricted to within $1 \mathrm{~km}$ of each of two nursery roosts of $\boldsymbol{R}$. hipposideros, in farm buildings at Baliynacally and Newhall, which lie about $9 \mathrm{~km}$ apart and within $13 \mathrm{~km}$ of Ennis, the largest town in County Clare. It is possible that lesser horseshoe bats other than those using these two roosts were included in this study. The terrain is predominantly permanent pasture with small to medium fields with mixed hedges (mostly alder Alnus glutinosa, ash Fraxinus excelsior, birch Betula pubescens, blackthorn Prunus spinosa, elm Ulmus procera, gorse Ulex europaeus, hazel Corylus avellana, hawthorn Crataegus monogyna, willow Salix species and even Fuschia magellanica) and occasional woodland strips or windbreaks (including mixtures of ash, fir Abies species, hawthorn, holly Ilex aquifolium, horse-chestnut Aesculus hippocastaneum, larch Larix decidua, lime Tilia europea, oak Quercus robur, sycamore Acer pseudoplatanus and Scots pine Pinus silvestris). The area is one of boulder-clay overlying limestone with drumlins (oval mounds of boulder-clay).

Seven habitat types were monitored: Trees: just outside the edge of woodland strip or windbreaks. Roadside: along minor country roads and lanes with hedges. Farmyard: farmyard with abundant droppings of domestic stock. One of these sites also contained a compost heap and another a sileage stack. Pasture: open grazed field. Sheltered water: an expanse of water densely fringed with trees. At Newhall this is at a lake and at Ballynacally by a slow-moving river. Open water: water without any tree cover nearby. This is available only at Newhall, at a lake. (Both lakes mentioned here are less than $0.2 \mathrm{~km}^{2}$ ). Creek: Ballynacally lies close to the estuary of the River Fergus. Three small streams, all only a few metres wide, the first of which is tidal, were included in this category. All run through pasture but there are a few trees in the vicinity of the streams in all cases. The habitat types monitored therefore all presented extensive open air space over which to receive the ultrasonic pulses of the bats. No monitoring was attempted within woodland strips, where sound reception might have been impeded.

The numbers of sites in each habitat type included in the two study areas are given in Table 1 . These were chosen by their availability, the logistics of visiting sufficient sites in a single night and by other considerations: for example it was apparent from initial field experience that it was probably uncommon for horseshoes to hunt over open pasture.

\section{METHODS}

From 14 May to September 1984 indications of foraging activity were obtained at the sites using a QMC 200 bat detector, which converts ultrasounds to audible frequencies. All or most of the sites in one study area could be visited in a single night, though operations were occasionally curtailed by rain, movement of livestock or by human presence and sometimes by the duration of darkness and the order in which the sites were visited (see below).

A site was monitored for $15 \mathrm{~min}$, this period being termed a 'run', with the detector tuned to $113 \mathrm{kHz}$. It thus picked up sounds from about $108-118 \mathrm{kHz}$. This is the effective range of the lesser horseshoe, which belongs to the Rhinolophidae, and higher than that of the highest pitched vocalisations of the six 


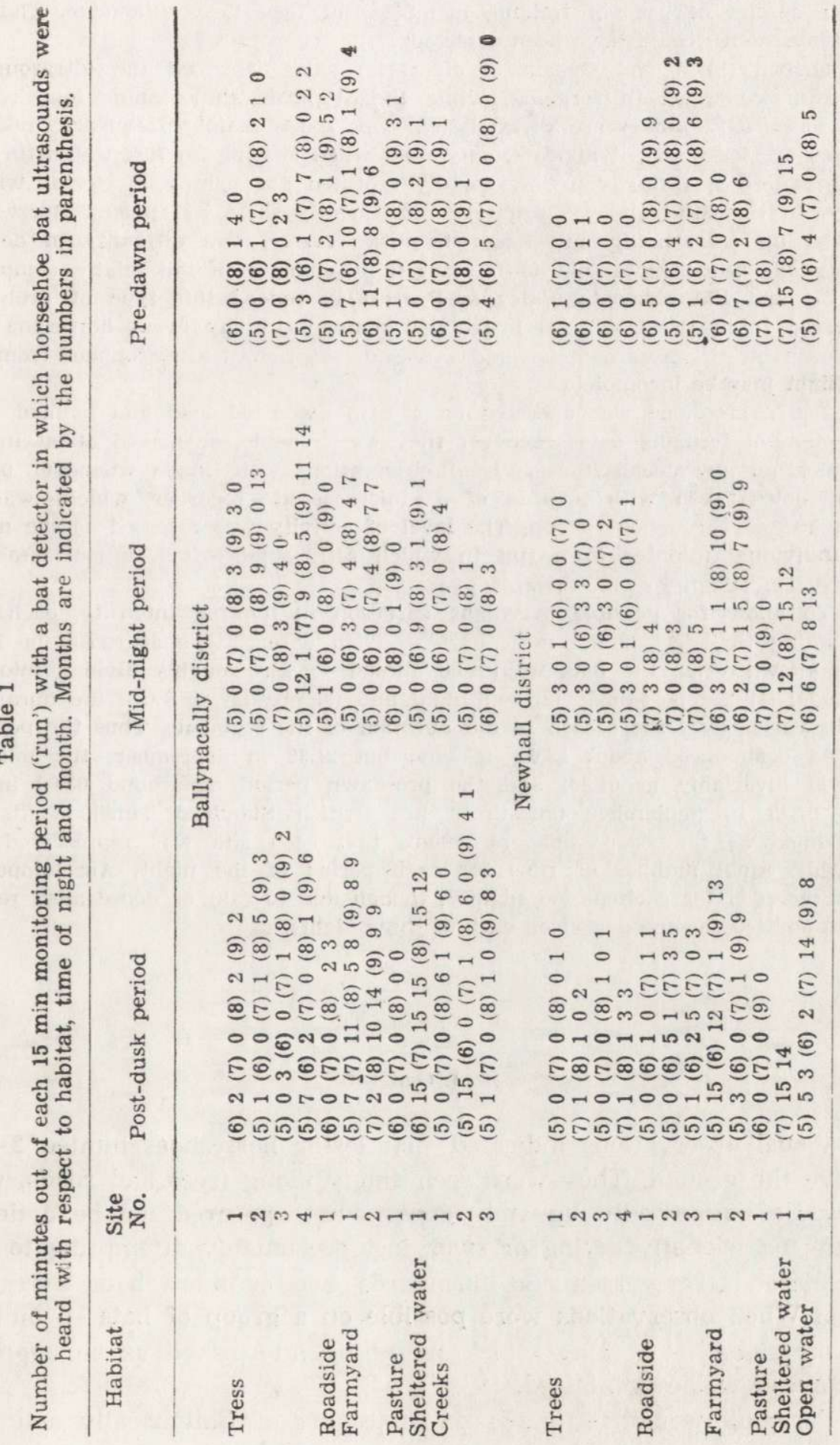


other species of bat in Ireland, members of the Vespertilionidae. Thus only $R$. hipposideros could have been detected.

Griffin (1962) and Griffin et al. (1962) have described the ultrasounds of the Rhinolophidae. In foraging, while the typical rhinolophid long constant frequency (CF) pulses are certainly emitted, short, mainly frequency modulated pulses are used and, it appears, only used when chasing an insect (Griffin et al., 1962). There is a final 'buzz' of rapidly repeated FM sounds on closing with the prey. In this study it was usual to hear mainly short FM pulses. Buzzes were picked up occasionally and long CF pulses rarely. The difficulty in detecting the whole sequence is said to be caused by changes in the relative amplitudes of CF and FM elements (Sales \& Pye, 1974). Indeed this type of problem is referred to in the QMC 200 instruction manual. In any event horseshoe sound emissions are highly directional and so sound reception at a microphone from a bat in flight may be incomplete.

The microphone was operated on a $2 \mathrm{~m}$ extension lead and pointed in the direction of foraging bats whenever they were visible, or moved about in order to pick up any vocalisations. Visual observations were made whenever possible and notes taken with the aid of a microcassette recorder, which was kept switched on throughout a run. The level of activity was assessed as the number of individual minutes in a run in which ultrasounds of $R$. hipposideros were heard (i.e. an integer value from 1 to 15 ).

To allow for possible overnight variation in hunting intensity, each night, excluding twilight for the most part - from observations at roosts in 1983 it was known when the bats would be abroad - was roughly divided into three periods: (1) the post-dusk, (2) mid-night and (3) pre-dawn. Since the duration of night varied over the season so did duration of the segments. Thus the post-dusk period commenced about 23.00 in June but 21.30 in September; the mid-night period invariably at 01.30 ; and the pre-dawn period at around 03.00 in June but $\mathbf{0 4 . 4 5}$ in September (all times are British Standard Time). Visits were scheduled as far as possible to ensure that each site was represented by a roughly equal number of runs for each period of the night. Air temperature was recorded for each period nightly, though due to rain or dense mist, readings were omitted for one period on each of three nights.

\section{RESULTS}

\section{General}

Visual observations indicated that lesser horseshoes hunted $2-5 \mathrm{~m}$ above the ground. They were seen singly along trees and roads, where they flew repeatedly up and down what appeared to be a definite route, occasionally diving or swerving, presumably attempting to catch an insect. Over water and farmyards two or more bats were often seen. When observations were possible on a group of bats - on about 50 occasions - nothing which might be interpreted as an aggressive encounter was ever noticed.

Foraging was investigated on 15 nights at Ballynacally and 14 at 
Newhall. Table 1 gives the number of runs undertaken at the various sites, their distribution by month and period of night, and the number of minutes in each run when horseshoe ultrasounds were detected. These results were tested with respect to habitat, time of night and month. Unfortunately a non-parametric test is required for such data and there are none suitable for three-way analysis of variance. The Kruskal-Wallis test (yielding the statistic $H$ ) was therefore used to examine the three types of variation individually and test for significant differences between means. The actual run means given in Tables 24 are, on the other hand, expressed throughout as geometric means of logarithmically transformed figures, namely: Antilog $((\Sigma \log (x+$ $+0.5)) / \mathrm{n})-0.5$. This was preferred because of the heterogeneous nature of the data and particularly the large number of zeros.

The (arithmetic) mean values for temperature for the three periods of the night were, respectively: $13.8^{\circ} \mathrm{C}, 12.0^{\circ} \mathrm{C}$ and $10.6^{\circ} \mathrm{C}$ for Newhall, and $14.8^{\circ} \mathrm{C}, 13.7^{\circ} \mathrm{C}$ and $12.4^{\circ} \mathrm{C}$ for Ballynacally. The summer of 1984 was exceptionally fine. There was rain on parts of two nights of observation only and wind, at most, was a fresh breeze.

\section{Habitat Preference}

The means for runs at individual sites and for habitat types, for the two study areas separately and combined, are given in Table 2 . It is clear that there were marked, and statistically highly significant, differences between habitats, differences that were consistent for both study areas. Foraging intensity was greatest beside expanses of water and at farmyards. Sites beside trees and roadside hedgerows were less

Table 2

Relative usage by lesser horseshoe bats of different habitat types and individual sites therein. Each result is the geometric mean of the numbers of minutes in the 15 min monitoring periods with a bat detector (runs) in which horseshoe ultrasounds were heard. Figures in parenthesis are results for individual sites, when there were more than one. The asterisk indicates the result for Trees when the data from site 4 at Ballynacally are omitted. $H$ is the Kruskal-Wallis statistic.

\begin{tabular}{|c|c|c|c|}
\hline Habitat & Ballynacally & Newhall & Combined data \\
\hline Trees & $1.2 * 0.8\left(\begin{array}{lllll}0.8 & 0.9 & 0.7 & 3.0\end{array}\right)$ & $0.4\left(\begin{array}{llll}0.2 & 0.8 & 0.3 & 0.6\end{array}\right)$ & $0.8 * 0.6$ \\
\hline Roadside & 0.6 & $1.2\left(\begin{array}{lll}1.1 & 1.1 & 1.5\end{array}\right)$ & 1.0 \\
\hline Farmyard & $4.4(4.3 \quad 4.5)$ & $2.4\left(\begin{array}{ll}1.8 & 3.1\end{array}\right)$ & 3.3 \\
\hline Pasture & 0.2 & 0 & 0.1 \\
\hline Sheltered water & 2.9 & 12.8 & 4.5 \\
\hline Open water & $\overline{0}(0=0007)$ & 3.7 & \\
\hline Creeks & $\left.\begin{array}{llll}0.7 & (0.5 & 0.8 & 0.7\end{array}\right)$ & - & 0.7 \\
\hline$H$ & $36.658 p<0.001$ & $49.967 p<0.001$ & $70.643 p<0.001$ \\
\hline
\end{tabular}


frequently used but still important. The bats were rarely detected over pasture. Nevertheless, $R$. hipposideros was recorded at some time at almost every site sampled.

It may be noted that if the values for Trees at site (4) at Ballynacally, which are generally higher, are omitted, then overall activity for Roadside is significantly higher at the $5 \%$ level than for Trees (Mann-Whitney $U$ test: normal statistic $=1.937, p<0.06$ ).

\section{Variation in Overnight Activity}

Run means for the three periods of the night for Ballynacally and Newhall individually and for total data are given in Table 3 . The figures for the combined data are statistically significant and the trend in both areas the same - an overnight decrease in activity, although it was still appreciable in the pre-dawn period. Because the significance level is only $5 \%$, it might be argued that it could be due to some sampling bias, with the intensively used habitats (Farmyard and Sheltered and Open water) being over-represented earlier in the night. But identical trends emerge if the means for the intensively used habitats $(6.94,2.99,2.00)$ and the others $(0.85,0.73,0.61)$ are considered is two separate groupings.

Individual sites were also examined for overnight changes in use, applying Siegel's (1956) tables for $H$ when values were low. Three sites produced significant results: at Ballynacally: Farmyard (1) (7.79, 2.55, 3.31, $H=6.051,2 \mathrm{df}, p<0.05)$ and Sheltered water $(14.35,1.56$, $0.48, H=9.411,2 \mathrm{df}, p<0.01)$; and at Newhall: Farmyard (1) (7.41, 1.61, $0,2 \mathrm{df}, p<0.05$ ). In all three cases activity was greatest in the post-dusk period.

Table 3

Variation in overnight activity of lesser horseshoe bats shown by dividing the night into three segments (see text). Each result is the geometric mean of the numbers of minutes in the 15 min monitoring periods with a bat detector ('runs') in which horseshoe ultrasounds were heard. $H$ is the Kruskall-Wallis statistic.

\begin{tabular}{lccc}
\hline Sample period & Ballynacally & Newhall & Combined data \\
\hline Post-dusk & 1.90 & 1.37 & 1.65 \\
Mid-night & 1.07 & 1.35 & 1.19 \\
Pre-dawn & 0.95 & 0.85 & 0.91 \\
\hline$H$ & $5.596 p<0.06$ & $2.066 \mathrm{NS}$ & $6.083 p<0.05$ \\
\hline
\end{tabular}




\section{Seasonal Variation in Foraging Activity}

Table 4 shows run means for months for both study areas and for pooled data, the result for which is highly significant. Again the pattern is the same in both areas, namely an intensification of foraging activity towards the end of the season. Once more the influence of a possible imbalance in the intensively used habitats (as defined above) may be discounted, as the tendency in these treated separately $(1.48$, $3.28,3.44,5.53,5.20)$ and that in the remaining data $(0.69,0.59,0.32$, $0.96,1.76)$ are also towards increased activity in late summer and early autumn.

Table 4

Variation in activity of lesser horseshoe bats with season. Each result is the geometric mean of the numbers of minutes in the 15 min monitoring periods with a bat detector ('runs') in which horseshoe ultrasounds were heard. $H$ is the Kruskall-Wallis statistic.

\begin{tabular}{|c|c|c|c|}
\hline Month & Ballynacally & Newhall & Combined data \\
\hline May & 0.94 & 0.74 & 0.84 \\
\hline June & 0.88 & 1.18 & 1.05 \\
\hline July & 0.66 & 0.92 & 0.80 \\
\hline August & 1.63 & 1.71 & 1.66 \\
\hline September & 2.29 & 3.18 & 2.48 \\
\hline$H$ & $12.206 p<0.05$ & $7.874 \mathrm{NS}$ & $19.284 p<0.001$ \\
\hline
\end{tabular}

\section{DISCUSSION}

Lesser horseshoe bats were found feeding on every habitat examined although some were utilised more than others: activity was greater in farmyards and around expanses of water than along roadside hedgerow, which in turn was more intense than that alongside woodland strip, which was again greater than that over open pasture. The distinction in the level of foraging activity between Roadside and Trees is valid only if the results from Tree site (4) at Ballynacally are excluded. The exceptionally high values from this site are almost certainly because sampling was along a track over which cows were driven daily to and from milking. Because substantial quantities of manure were present at this site it effectively approximated to Farmyard. Indeed the mean value for foraging activity is comparable with those from Farmyard.

The only other detailed study of habitat preference by (insectivorous) bats in the British (Isles was by Racey \& Swift (1985), who used light tags to track pipistrelles Pipistrellus pipistrellus (Schreber). Their 
findings may be summarized thus. Foraging was concentrated over water (rivers and ponds), particularly in areas with trees and thick undergrowth, but occurred around trees as well. Rivers and lines of trees were used too as routes to the main feeding areas. Open fields and hills were avoided. It was concluded that the favoured sites were those where insect density was high; it is low in exposed situations. Racey \& Swift also drew attention to the frequency of reports in the literature of foraging by insectivorous bats over water and riparian vegetation in temperate and tropical habitats. Concentration of feeding around water is moreover stressed by Fenton (1970) and Fenton et al. (1973). The importance of expanses of water to lesser horseshoes, even apparently expanses of water not surrounded by trees, is clear, and areas of vegetation evidently receive more attention than open ones. Doubtless relative insect abundance dictates the extent of hunting here too. It is worth emphasizing that visual observations on group size reflected results obtained with the bat detector. So individuals were seen to operate singly along the edge of trees and hedges, while groups were seen over water and farmyards.

Farmyard would indeed appear to be an additional optimal habitat for the lesser horseshoes. A study of the diet of R. hipposideros in County Clare (McAney \& Fairley, 1989) showed that a wide variety of insects was consumed, but nematoceran Diptera appeared in over a third of the faecal pellets examined. The abundance of decaying organic matter in farmyards (and at Tree site (4) at Ballynacally) could well have resulted in a local concentration of Nematocera.

Fenton (1983) and Hill \& Smith (1984) have concisely summarized the overnight patterns of feeding in bats. Hunting begins a little before or at dusk and may continue throughout the night interspersed with periods of rest at the daytime quarters or at night roosts. However activity may centre on particular periods, mostly at dusk and dawn. Unfortunately much of the earlier information was obtained by direct capture and may be misleading, the more recent use of bat detectors and other means of remote observation having led to modification of earlier conclusions.

While lesser horseshoe bats were found to forage throughout the hours of darkness - possibly a reflection of the wide range of prey taken - there was a distinct fall-off in intensity as the night progressed. In addition, where significant variation was detected at individual sites, there was a pronounced concentration of feeding after dusk. In this context it is of particular interest that overnight observations at the nursery roosts at Newhall and Ballynacally (McAney \& Fairley, 1988) showed that an appreciable number of 
individuals returned to the roost well before dawn and remained there.

Williams (1939) amassed extensive data on the abundance of night-flying insects in southern England by light-trapping and demonstrated a clear overnight decline in their numbers. If a similar pattern in availability of insects can be inferred for our study areas, it would readily explain the parallel decrease in hunting by bats.

There was an increase in foraging towards the end of the season in both study areas, before the bats departed to their hibernacula at the end of September or in October. That this was not significant at the $5 \%$ level at Newhall is no doubt due to fewer data there in September (Table 1). This surge may conceivably have been influenced by the young taking to the wing and augmenting the population. On the other hand it would be an advantage to all bats to increase fat reserves before entering hibernation, which would be facilitated by the capture of more insects.

Acknowledgements: We would like to express our gratitude to landowners for access to their properties, in particular the Garry family of Ballynacally and the Joyce family of Newhall.

\section{REFERENCES}

1. Fenton M.B., 1970: A technique for monitoring bat activity with results obtained from different environments in southern Ontario. Can. J. Zool., 48: $847-851$.

2. Fenton M.B., 1983: Just bats. University of Toronto Press: 1-166, Toronto.

3. Fenton M.B., Jacobsen S.L. \& Stone R.N., 1973: An automatic sensing system for monitoring the activity of some bats. Can. J. Zool., 51: 291-299.

4. Gaisler J., 1963a: The ecology of the lesser horseshoe bat (Rhinolophus hipposideros hipposideros Bechstein, 1800) in Czechoslovakia, Part I. Vest. csl. Spol. zool., 27: 211-233.

5. Gaisler J., 1963b: The ecology of the lesser horseshoe bat (Rhinolophus hipposideros hipposideros (Bechstein, 1800) in Czechoslovakia II: Ecological demands, problem of synantrophy. Vest. csl. Spol. zool., 27: 322-327.

6. Gaisler J., 1963c: Nocturnal activity in the lesser horseshoe bat, Rhinolophus hipposideros (Bechstein). Zool. Listy., 12: 223-230.

7. Griffin D.R., 1962: Comparative studies on the orientation sounds of bats. Symp. zool. Soc. Lond., 7: 31-72.

8. Griffin D., Dunning D.C., Cahlender D.A. \& Webster F.A., 1962: Correlated orientation sounds and ear movements of horseshoe bats. Nature, Lond., 4860: $1185-1186$

9. Hill J.E. \& Smith J.D., 1984: Bats: a natural history. British Museum (Natural History): 1-243, London.

10. McAney C.M. \& Fairley J.S., 1988: Activity patterns of the lesser horseshoe bat Rhinolophus hipposideros at summer roosts. J. Zool., Lond., 216: 325-338. 
11. McAney, C.M. \& Fairley, J.S., 1989: Analysis of the diet of the lesser horseshoe bat Rhinolophus hipposideros in the West of Ireland. J. Zool., Lond., (in press).

12. Racey P.A. \& Swift S.M., 1985: Feeding ecology of Pipistrellus pipistrellus (Chiroptera: Vespertilionidae) during pregnancy and lactation. I. Foraging behaviour. J. Anim. Ecol., 54: 205-215.

13. Sales G. \& Pye J.D. 1974: Ultrasonic communication by animals. Chapman \& Hall: $1-28 \overline{1}$, London.

14. Siegel S., 1956: Nonparametric statistics for the behavioural sciences. McGraw Hill: $1-312$, New York.

15. Stebbings R.E. \& Griffith F., 1986: Distribution and status of bats in Europe. Institute for Terrestrial Ecology: 1-142, Monks Wood.

16. Williams C.B., 1939: An analysis of four years captures of insects in a light-trap. Part I. General survey; sex proportion; phenology; and time of flight. Trans. R. ent. Soc. Lond., 89: 79-132.

Received 10 March 1988, Accepted 25 July 1988.

Catherine M. McANEY i James S. FAIRLEY

\section{WYBIORCZOSC SRODOWISKOWA I ZMIENNOSC AKTYWNOSCI ZEROWANIA PODKOWCA MALEGO}

\section{Streszczenie}

Ultradźwięki wydawane w czasie żerowania przez Rhinolophus hipposideros (Bechstein, 1800) rejestrowano nocą, regularnie od maja do września. Rejestracji dokonywano w okresach 15 minutowych, w różnorodnych miejscach, w dwóch regionach zachodniej Irlandii, przeważnie o charakterze pastwiskowym. Sygnały były najczęstsze nad wodami i zagrodami farmerów, mniej częste wzdłuż zadrzewień i zakrzaczeń i stosunkowo rzadkie nad otwartymi pastwiskami (Tabela 2). Aktywność żerowania zmniejszała się w ciągu nocy, chociaż przed świtem nietoperze były nadal aktywne (Tabela 3). Aktywność zwiększała się pod koniec lata (Tabela 4). W pracy są dyskutowane prawdopodobne przyczyny przestrzennego i czasowego zróżnicowania aktywności żerowej. 